\title{
Design, finite element analysis (FEA), and fabrication of custom titanium alloy cranial implant using electron beam melting additive manufacturing
}

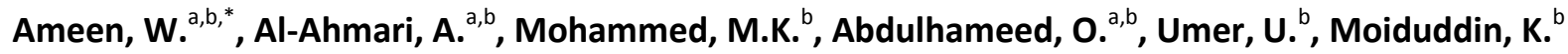 \\ ${ }^{a}$ Industrial Engineering Department, King Saud University, Kingdom of Saudi Arabia \\ ${ }^{b}$ Princess Fatima Alnijiris's Research Chair for Advanced Manufacturing Technology (FARCAMT Chair), Advanced Manufac- \\ turing Institute, King Saud University, Kingdom of Saudi Arabia
}

\section{A B S T R A C T}

Skull defect reconstruction is one of the most difficult challenges faced by the surgeons because of the complex shape of the skull. Skull defects are dramatically increasing with the increase in road accidents, tumors, and wars, thereby increasing the demand for reconstruction of skull. It is difficult to manufacture standard implants for skull defects especially for large and complex defects, due to the complexity and the difference in anatomy of skulls. Design and fabrication of custom cranial implant is required in these cases. The conventional technologies face multiple challenges in fabricating lightweight custom cranial implants closer to that of bone in terms of weight; the difference in the weight introduces stress-shielding effects onto the surrounding bone. In order to overcome this problem, several researches proposed lattice structure implants fabricated by additive manufacturing. However, lattice structure implants are difficult to remove later when some problems are encountered. This paper presents a methodology of design analysis and fabrication of solid lightweight custom cranial implant using additive manufacturing. A Case study is presented where, a custom cranial implant is designed and analysed using finite element analysis (FEA) and then fabricated using electron beam melting (EBM) additive manufacturing. The titanium alloy Ti6Al4V which is biocompatible and non-toxic is used as the implant material. The functionality, fitting, and aesthetic of the proposed design are evaluated. The results show the successful fabrication of thin custom cranial implant for skull defect reconstruction via EBM technology. The fabricated implant has sufficient strength, weight close to the weight of the removed bone portion while maintaining a good fit and aesthetics.
\end{abstract}

\section{ARTICLE INFO}

Keywords:

Additive manufacturing;

Cranial implant;

Titanium alloy (Ti6Al4V);

Electron beam melting (EBM);

Finite element analysis (FEA)

*Corresponding author: wadeaameen@gmail.com (Ameen, W.)

Article history:

Received 17 July 2018

Revised 13 August 2018

Accepted 24 August 2018

\section{References}

[1] Gibson, I., Rosen, D.W., Stucker, B. (2010). Additive manufacturing technologies: Rapid prototyping to direct digital manufacturing, Springer, New York, USA, doi: 10.1007/978-1-4419-1120-9.

[2] Morgan, L., Lindhe, U., Harrysson, O. (2003). Rapid manufacturing with electron beam melting (EBM) - A manufacturing revolution?, In: Proceedings of Annual International Solid Freeform Fabrication Symposium - An Additive Manufacturing Conference, Austin, Texas, USA, 433-438.

[3] Berce, P., Chezan, H., Balc, N. (2005). The application of rapid prototyping technologies for manufacturing the custom implants, In: Proceedings of 8th ESAFORM Conference on Material Forming, Cluj-Napoca, Romania, 27-29. 
[4] Christensen, A., Kircher, R., Lippincott, A. (2008). Qualification of electron beam melted (EBM) Ti6Al4V-ELI for orthopaedic applications, In: Proceedings of MPMD, Materials and Processes for Medical Devices Conference, Palm Desert, USA, 48-53.

[5] Li, X., Wang, C., Zhang, W., Li, Y. (2009). Fabrication and characterization of porous Ti6Al4V parts for biomedical applications using electron beam melting process, Materials Letters, Vol. 63, No. 3-4, 403-405, doi: 10.1016/i.matlet. $\underline{2008.10 .065 .}$.

[6] Abdel-Haleem, A.K., Nouby, R., Taghian, M. (2011). The use of the rib grafts in head and neck reconstruction, Egyptian Journal of Ear, Nose, Throat and Allied Sciences, Vol. 12, No. 2, 89-98, doi: 10.1016/i.ejenta.2011.08.004.

[7] He, Y., Ye, M., Wang, C. (2006). A method in the design and fabrication of exact-fit customized implant based on sectional medical images and rapid prototyping technology, The International Journal of Advanced Manufacturing Technology, Vol. 28, No. 5-6, 504-508, doi: 10.1007/s00170-004-2406-y.

[8] Durham, S.R., McComb, J.G., Levy, M.L. (2003). Correction of large ( $>25 \mathrm{~cm}^{2}$ ) cranial defects with "reinforced" hydroxyapatite cement: Technique and complications, Neurosurgery, Vol. 52, No. 4, 842-845, doi: 10.1227/01.NEU. $\underline{0000054220.01290 .8 \mathrm{E} .}$

[9] Ducic, Y. (2002). Titanium mesh and hydroxyapatite cement cranioplasty: A report of 20 cases, Journal of oral and maxillofacial surgery, Vol. 60, No. 3, 272-276, doi: 10.1053/joms.2002.30575.

[10] Engstrand, T., Kihlström, L., Lundgren, K., Trobos, M., Engqvist, H., Thomsen, P. (2015). Bioceramic implant induces bone healing of cranial defects, Plastic and Reconstructive Surgery - Global Open, Vol. 3, No. 8, doi: 10.1097/GOX.000 $\underline{0000000000467 .}$

[11] Charnley, G., Judet, T., Pirou, P., Garreau de Loubresse, C. (2000). Titanium femoral component fixation and experience with a cemented titanium prosthesis, In: Learmonth, I.D. (ed.), Interfaces in total hip arthroplasty, Springer, London, UK, 3-10, doi: 10.1007/978-1-4471-0477-3 1.

[12] Moiduddin, K., Darwish, S., Al-Ahmari, A., ElWatidy, S., Mohammad, A., Ameen, W. (2017). Structural and mechanical characterization of custom design cranial implant created using additive manufacturing, Electronic Journal of Biotechnology, Vol. 29, 22-31, doi: 10.1016/i.ejbt.2017.06.005.

[13] Niinomi, M. (2008). Mechanical biocompatibilities of titanium alloys for biomedical applications, Journal of the Mechanical Behavior of Biomedical Materials, Vol. 1, No. 1, 30-42, doi: 10.1016/j.jmbbm.2007.07.001.

[14] Schipper, J., Ridder, G.J., Spetzger, U., Teszler, C.B., Fradis, M., Maier, W. (2004). Individual prefabricated titanium implants and titanium mesh in skull base reconstructive surgery. A report of cases, European Archives of Oto-RhinoLaryngology and Head \& Neck, Vol. 261, No. 5, 282-290, doi: 10.1007/s00405-003-0686-8.

[15] Mazzoli, A., Germani, M., Raffaeli, R. (2009). Direct fabrication through electron beam melting technology of custom cranial implants designed in a PHANToM-based haptic environment, Materials \& Design, Vol. 30, No. 8, 3186-3192, doi: 10.1016/i.matdes.2008.11.013.

[16] Goyal, S., Goyal, M. K. (2014). Restoration of large cranial defect for cranioplasty with alloplastic cranial implant material: A case report, The Journal of Indian Prosthodontic Society, Vol. 14, No. 2, 191-194, doi: 10.1007/s13191012-0185-y.

[17] Lieger, O., Richards, R., Liu, M., Lloyd, T. (2010). Computer-assisted design and manufacture of implants in the late reconstruction of extensive orbital fractures, Archives of Facial Plastic Surgery, Vol. 12, No. 3, 186-191, doi: 10.1001/archfacial.2010.26.

[18] Joffe, J.M., Nicoll, S.R., Richards, R., Linney, A.D., Harris, M. (1999). Validation of computer-assisted manufacture of titanium plates for cranioplasty, International Journal of Oral and Maxillofacial Surgery, Vol. 28, No. 4, 309-313, doi: 10.1016/S0901-5027(99)80165-9.

[19] da Costa, D.D., Pedrini, H., Bazan, O. (2009). Direct milling of polymethylmethacrylate for cranioplasty applications, The International Journal of Advanced Manufacturing Technology, Vol. 45, No. 3-4, 318-325, doi: 10.1007/s00170009-1978-y.

[20] da Costa, D.D., Lajarin, S.F. (2012). Comparison of cranioplasty implants produced by machining and by casting in a gypsum mold, The International Journal of Advanced Manufacturing Technology, Vol. 58, No. 1-4, 1-8, doi: 10.1007/s00170-011-3388-1.

[21] Saldarriaga, J.F.I., Vélez, S.C., Posada, M.D.A.C., Henao, I.E.B.B., Valencia, M.E.C.A.T. (2011). Design and manufacturing of a custom skull implant, American Journal of Engineering and Applied Sciences, Vol. 4, No. 1, 169-174, doi: 10.3844/ajeassp.2011.169.174.

[22] Dujovne, A.R., Bobyn, J.D., Krygier, J.J., Miller, J.E., Brooks, C.E. (1993). Mechanical compatibility of noncemented hip prostheses with the human femur, The Journal of Arthroplasty, Vol. 8, No. 1, 7-22, doi: 10.1016/S0883-5403 (06)80102-6.

[23] Parthasarathy, J. (2014). 3D modeling, custom implants and its future perspectives in craniofacial surgery, Annals of Maxillofacial Surgery, Vol. 4, No. 1, 9-18, doi: 10.4103/2231-0746.133065.

[24] Cho, H.R., Roh, T.S., Shim, K.W., Kim, Y.O., Lew, D.H., Yun, I.S. (2015). Skull reconstruction with custom made threedimensional titanium implant, Archives of Craniofacial Surgery, Vol. 16, No. 1, 11-16, doi: 10.7181/acfs.2015. 16.1.11.

[25] Murr, L.E., Gaytan, S.M., Martinez, E., Medina, F., Wicker, R.B. (2012). Next generation orthopaedic implants by additive manufacturing using electron beam melting, International Journal of Biomaterials, Vol. 2012, doi: 10.1155/ $\underline{2012 / 245727}$

[26] Al-Ahmari, A., Nasr, E.A., Moiduddin, K., Alkindi, M., Kamrani, A. (2015). Patient specific mandibular implant for maxillofacial surgery using additive manufacturing, In: Proceedings of 2015 International Conference on Industrial Engineering and Operations Management (IEOM), Dubai, UAE, 1-7, doi: 10.1109/IEOM.2015.7093788.

[27] Mazzoli, A., Germani, M., Raffaeli, R. (2009). Direct fabrication through electron beam melting technology of custom cranial implants designed in a PHANToM-based haptic environment, Materials \& Design, Vol. 30, No. 8, 3186-3192, doi: 10.1016/i.matdes.2008.11.013. 
[28] Li, X., Wang, C., Zhang, W., Li, Y. (2009). Fabrication and characterization of porous Ti6Al4V parts for biomedical applications using electron beam melting process, Materials Letters, Vol. 63, No. 3-4, 403-405, doi: 10.1016/i.matlet. 2008.10 .065$.

[29] Saldarriaga, J.F.I., Vélez, S.C., Posada, M.D.A.C., Henao, I.E.B.B., Valencia, M.E.C.A.T. (2011). Design and manufacturing of a custom skull implant, American Journal of Engineering and Applied Sciences, Vol. 4, No. 1, 169-174, doi: 10.3844/ajeassp.2011.169.174.

[30] Syam, W.P., Al-Shehri, H.A., Al-Ahmari, A.M., Al-Wazzan, K.A., Mannan, M.A. (2012). Preliminary fabrication of thinwall structure of Ti6Al4V for dental restoration by electron beam melting, Rapid Prototyping Journal, Vol. 18, No. 3, 230-240, doi: 10.1108/13552541211218180.

[31] Al-Ahmari, A., Nasr, E.A., Moiduddin, K., Anwar, S., Al Kindi, M., Kamrani, A. (2015). A comparative study on the customized design of mandibular reconstruction plates using finite element method, Advances in Mechanical Engineering, Vol. 7, No. 7, doi: 10.1177/1687814015593890.

[32] Tsouknidas, A., Maropoulos, S., Savvakis, S., Michailidis, N. (2011). FEM assisted evaluation of PMMA and Ti6Al4V as materials for cranioplasty resulting mechanical behaviour and the neurocranial protection, Bio-Medical Materials and Engineering, Vol. 21, No. 3, 139-147, doi: 10.3233/BME-2011-0663.

[33] Allen, T., Goodwill, S., Haake, S. (2008). Experimental validation of a tennis ball finite-element model for different temperatures, In: Estivalet, M., Brisson, P. (eds.), The Engineering of Sport 7, Springer Nature, Switzerland, 125-133, doi: 10.1007/978-2-287-09411-8 15.

[34] Chamrad, J., Marcián, P., Borák, L., Wolff, J. (2016). Finite element analysis of cranial implant, In: Proceedings of 32nd conference with international participation computational mechanics, Železná Ruda, Czech Republic, doi: 10.13140/ RG.2.2.19870.13124.

[35] Parle, D., Ambulgekar, A., Gaikwad, K. (2015). Patient specific design and validation of cranial implants using FEA, In: Altair Technology Conference, Bengaluru, India, 1-9.

[36] Ridwan-Pramana, A., Marcián, P., Borák, L., Narra, N., Forouzanfar, T., Wolff, J. (2017). Finite element analysis of 6 large PMMA skull reconstructions: A multi-criteria evaluation approach, Plos One, Vol. 12, No. 6, doi: 10.1371/ journal.pone.0179325.

[37] Koike, M., Martinez, K., Guo, L., Chahine, G., Kovacevic, R., Okabe, T. (2011). Evaluation of titanium alloy fabricated using electron beam melting system for dental applications, Journal of Materials Processing Technology, Vol. 211, No. 8, 1400-1408, doi: 10.1016/j.jmatprotec.2011.03.013.

[38] Karlsson, J. (2015). Optimization of electron beam melting for production of small components in biocompatible titanium grades, Doctoral thesis, Acta universitatis upsaliensis.

[39] Margulies, S.S., Thibault, K.L. (2000). Infant skull and suture properties: Measurements and implications for mechanisms of pediatric brain injury, Journal of Biomechanical Engineering, Vol. 122, No. 4, 364-371, doi: 10.1115/1. $\underline{1287160 .}$.

[40] Ameen, W., Al-Ahmari, A., Mohammed, M.K., Mian, S.H. (2018). Manufacturability of overhanging holes using electron beam melting, Metals, Vol. 8, No. 6, 1-24, doi: 10.3390/met8060397.

[41] Al-Ekrish, A.A., Alfadda, S.A., Ameen, W., Hörmann, R., Puelacher, W., Widmann, G. (2018). Accuracy of computeraided design models of the jaws produced using ultra-low MDCT doses and ASIR and MBIR, International Journal of Computer Assisted Radiology and Surgery, 1-8, doi: 10.1007/s11548-018-1809-4.

[42] Čolić, K., Sedmak, A., Legweel, K., Milošević, M., Mitrović, N., Mišković, Ž., Hloch, S. (2017). Experimental and numerical research of mechanical behaviour of titanium alloy hip implant, Tehnički vjesnik - Technical Gazette, Vol. 24, No. 3, 709-713, doi: 10.17559/TV-20160219132016.

[43] Ramakrishnaiah, R., Al Kheraif, A.A., Mohammad, A., Divakar, D.D., Kotha, S.B., Celur, S.L., Hashem, M.I., Vallittu, P.K., Rehman, I.U. (2017). Preliminary fabrication and characterization of electron beam melted Ti-6Al-4V customized dental implant, Saudi Journal of Biological Sciences, Vol. 24, No. 4, 787-796, doi: 10.1016/j.sjbs.2016.05.001. 


\title{
Oblikovanje, analiza z metodo končnih elementov (MKE) in izdelava lobanjskega vsadka iz titanove zlitine $z$ uporabo dodajalne tehnologije taljenja z elektronskim žarkom
}

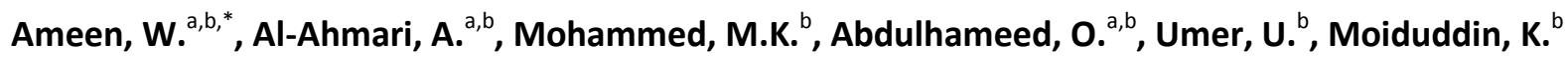 \\ ${ }^{a}$ Industrial Engineering Department, King Saud University, Kingdom of Saudi Arabia \\ brincess Fatima Alnijiris's Research Chair for Advanced Manufacturing Technology (FARCAMT Chair), Advanced Manufac- \\ turing Institute, King Saud University, Kingdom of Saudi Arabia
}

\section{POVZETEK}

Rekonstrukcija okvare lobanje je zaradi kompleksne oblike lobanje eden najtežjih izzivov, s katerim se soočajo kirurgi. Število okvar lobanje se z naraščanjem števila prometnih nesreč, tumorjev in vojn dramatično povečuje, s čimer se povečuje tudi povpraševanje po rekonstrukciji lobanje. Zaradi kompleksnosti in razlike $\mathrm{v}$ anatomiji lobanj je težko izdelati standardne vsadke za okvare lobanj, zlasti za velike in zapletene okvare. $\mathrm{V}$ takih primerih je treba lobanjski vsadek izdelati po meri. Konvencionalni postopki se soočajo s številnimi izzivi pri izdelavi lahkih namenskih lobanjskih vsadkov; predvsem je treba zagotoviti, da je teža vsadka primerljiva s težo okoliških kosti, saj morebitna razlika v teži ustvarja učinke napetost. Da bi to težavo premostili, so nekateri raziskovalci predlagali mrežno strukturo vsadka, izdelanega z dodajalnimi tehnologijami. Vendar pa je take vsadke v primeru težav težko odstraniti. V prispevku je predstavljena metoda analize zasnove in izdelave polnega in lahkega vsadka po meri, izdelanega $\mathrm{z}$ dodajalno tehnologijo. Predstavljena je študija primera, pri kateri smo lobanjski vsadek analizirali z metodo končnih elementov in ga nato izdelali s tehnologijo taljenja $\mathrm{z}$ elektronskim žarkom (EBM). Za material vsadka smo uporabili titanovo zlitino Ti6Al4V, ki je biokompatibilna in nestrupena. Vrednotile so se funkcionalnost, prileganje in estetika predlaganega vsadka. Rezultati so potrdili možnost uspešne izdelave tankega lobanjskega vsadka po meri za rekonstrukcijo okvare lobanje s tehnologijo EBM. Izdelan vsadek je imel zadostno trdnost, težo podobno teži odstranjenega kostnega deleža, hkrati pa se je dobro prilegal in imel ustrezen estetski videz.

\section{PODATKI O ČLANKU}

Ključne besede:

Dodajalna izdelava

Lobanjski vsadek

Titanova zlitina (Ti6Al4V)

Taljenje z elektronskim žarkom

(EBM)

Metoda končnih elementov (MKE)

*Kontaktna oseba:

wadeaameen@gmail.com

(Ameen, W.)

Zgodovina članka:

Prejet 17. julija 2018

Popravljen 13. avgusta 2018

Sprejet 24. avgusta 2018 